ISSN 0185-0121; e-ISSN 2448-6558; DOI: 10.24201/nrfh.v69i1.3715

\title{
ELEMENTOS TERRORÍFICOS \\ EN LA CRUEL ARAGONESA DE ALONSO DE CASTILLO SOLÓRZANO
}

\section{TERRIFYING ELEMENTS IN ALONSO DE CASTILLO SOLÓRZANO'S LA CRUEL ARAGONESA}

\author{
Eva Lara Alberola \\ Universidad Católica de Valencia \\ eva.lara@ucv.es \\ orcid: 0000-0001-5063-5424
}

\begin{abstract}
RESUMEN: Hay obras barrocas destacables por sus aspectos terroríficos y macabros, pero ninguna conjuga todos los elementos presentes en La cruel aragonesa, novela corta de Alonso de Castillo Solórzano (Jornadas alegres, 1626), donde hallamos a una mujer monstruosa capaz de ejecutar con gran crueldad los actos más terribles y asistimos a varios homicidios, a la profanación de cadáveres, al recurso de la magia negra y al tormento ejercido por las voces espectrales que persiguen a la protagonista. Estos aspectos, entre otros, a los que la crítica ha sido sistemáticamente indiferente, le aportan un marcado goticismo. Por ello, las siguientes páginas pretenden contribuir a la revaloración de esta novela corta de Castillo Solórzano y demostrar por qué los elementos que reúne la sitúan en un lugar privilegiado entre las de su especie.

Palabras clave: novela corta; siglo XvII; goticismo; terror sobrenatural; hechicería.
\end{abstract}

Abstract: This article attempts to prove that La cruel aragonesa, a short novel by Alonso de Castillo Solórzano (Jornadas alegres, 1626), is a text which, despite critical indifference, gathers together diverse ingredients that distinguish it as a gothic work or art. There are other Baroque works remarkable for their terrifying and macabre aspects, but none combines all the elements that appear in this novel, where we find a monstrous woman capable of performing terrible acts of great cruelty, and in which, among other things, we witness several homicides, the desecration of corpses, the resort to black magic and the torment exerted on the protagonist by the spectral voices that plague her.

Keywords: short novel; 17th century; Gothicism; supernatural terror; witchcraft.

Recepción: 31 de enero de 2019; aceptación: 2 de septiembre de 2019.

D.R. (C) 2021. Nueva Revista de Filología Hispánica Licencia Creative Commons Attribution-NonCommercial (CC BY-NC) 4.0 International 


\section{INTRODUCGIÓN*}

Este trabajo se integra en la investigación que estamos llevando a cabo sobre los antecedentes de la literatura gótica o de terror, género que se constituye a partir de la segunda mitad del siglo XVIII en Inglaterra (Ferreras 1973 y 1991; Carnero 1993; López Santos 2010) y que da lugar, posteriormente, a las letras fantásticas (Roas 2000; López Santos 2008). Se desarrolla en un momento histórico en el que ya no se cree en lo numinoso, lo que permite la recuperación de lo sobrenatural con una finalidad estética y de deleite (Lovecraft 2010; Llopis 2013; Ferreras 1973; Carnero 1983; Olavarría 1989; Glendinning 1994; Roas 2000; Martínez de Mingo 2004; López Santos 2008 y 2010, pp. 18-24; Sánchez-Verdejo 2013; Aldana 2017). En relación con lo dicho, todos los expertos avalan la existencia de ciertos precedentes que habrían marcado el camino conducente al género de terror ${ }^{1}$, aunque unos más cerca del horror que otros ${ }^{2}$.

Por su misma idiosincrasia, en España no se dio la misma eclosión de estas letras que en otros países europeos ${ }^{3}$, pero no se le puede

* El presente trabajo se inscribe en las actividades del Proyecto de I+D del Programa Estatal de Generación de Conocimiento (MCIU/FEDER) PGC2018-095757-BI00: Magia, épica e historiografía hispánicas: relaciones literarias y nomológicas II, dirigido por el doctor Alberto Montaner Frutos, y del Proyecto I+D para grupos emergentes: Figuras de lo insólito en la literatura de márgenes: fascinación y horror en el mundo hispánico (XVII-XIX) (GV/2020/207), financiado por la Conselleria d'Innovació, Universitats, Ciència i Societat Digital, dirigido por el doctor Juan Gomis Coloma.

${ }^{1}$ Se trata de los mismos estudios ya mencionados, entre los cuales habría que añadir ALDANa 2015

${ }^{2}$ De las tragedias de Sófocles, Eurípides y Esquilo a los Sueños de Quevedo (Llopis 2013, p. 28); de las lamias y harpías de la tradición griega a El peregrino en su patria de Lope de Vega (RoAs 2000, p. 65); del Calila e Dimna a los Desengaños amorosos de María de Zayas (Aldana 2017, pp. 6-9); desde Horacio, Petronio, Luciano y Apuleyo, hasta Torres Villarroel, Feijoo, Antonio Zamora, José de Cañizares, Botello de Moraes, pasando por las novelas de caballerías, los diálogos lucianescos, las novelas bizantinas, las misceláneas, las novelas cortesanas... (GONZÁlez DE VeGA 2017, pp. 13-148). Y no podemos olvidar otra vía que habría alumbrado multitud de textos interesantísimos que han pasado desapercibidos en relación con el terror: los tratados de magia y brujería, los manuales inquisitoriales, las actas de los procesos y las relaciones que sobre estas últimas circularían en multitud de ocasiones. A esto ya hacía referencia LOVECRAFT 2010, pp. 33-37. En nuestro trabajo en prensa (LARA Alberola 2021), se abordan precisamente estos géneros y se apuesta por crear una etiqueta específica: "literatura vivencial de terror" (se extendería sobre todo entre los siglos XV y XVII), con el fin de diferenciarla de aquella generada en un momento histórico en que ya no se cree en lo sobrenatural, de dotarla de entidad y de marcar la distancia con aquellas muestras que deberían considerarse simples antecedentes.

${ }^{3}$ López SANTos (2010, pp. 18-24) habla de las particularidades de España frente a otros países, aludiendo sobre todo a una ilustración insuficiente, por la presencia de unas "sombras" que no dejan que la luz se instaure, a causa de "un ambiente oscurantista" (que ella relaciona sobre todo con las creencias mágicas); por lo tanto, hay que hablar de la pervivencia de la superstición. Por lo demás, incide también en la censura como otra de las trabas que impide un total desarrollo de la novela 
negar una literatura gótica y fantástica, aunque en otra jerarquía, tal como han demostrado Roas (2000) y López Santos (2010), entre otros. Tanto si consideramos que en España faltó un mayor desarrollo del terror (Ferreras 1991), como si reconocemos que existieron representaciones del género (Díez de Revenga 2006; Roas 2000; López Santos 2010), es necesario indagar sobre aquellos textos anteriores a la decimoctava centuria que pueden considerarse de gran interés por la presencia de pasajes y elementos terroríficos; en definitiva, por su goticismo. En nuestro caso, nos centraremos en aquellas muestras en las que el horror sobrenatural colinda de algún modo con la magia. Como Lovecraft (2010) ha reconocido: el horror, la magia y la brujería están estrechamente relacionados; es más, aquél nace de éstas en gran medida.

El hecho de que hayamos optado por La cruel aragonesa de Antonio de Castillo Solórzano, relato cortesano incluido en las Jornadas alegres, de 1626, se debe a que el texto reúne, precisamente, ingredientes que tienen que ver tanto con la hechicería como con lo siniestro y mortuorio, con la monstruosidad y la crueldad, con el homicidio y la venganza y, por último, con lo espectral. Hay, evidentemente, otros textos llamativos con tales ingredientes, como ciertos pasajes de Varia fortuna del soldado Píndaro, de Gonzalo de Céspedes y Meneses, o La fuerza del amor, de María de Zayas. No obstante, La cruel aragonesa ha recibido menor atención y presenta ciertos aspectos que se hallan ausentes en otras obras que también pueden considerarse precedentes de la literatura gótica.

En el presente artículo se tratarán todos estos puntos, con el fin de reconocer la importancia del texto de Castillo Solórzano en cuanto al tema que nos ocupa. En posteriores trabajos se aportará, de forma más general, un panorama más amplio de los principales precedentes de las letras de terror, una vez analizadas pormenorizadamente las muestras más cruciales en distintos artículos.

\section{La cruel aragonesa de Alonso de Gastillo Solórzano}

Evidentemente, La cruel aragonesa no es un relato de terror, pues el género todavía no existe como tal en el siglo xvir. Se trata de una novela corta sentimental de Alonso de Castillo Solórzano incluida en las Jornadas alegres, de $1626^{4}$. Su núcleo, por tanto, es la relación amorosa entre doña Clara, la protagonista, y don García. Eso sí, la relación

gótica (pp. 24-40). Eso sí, defiende la existencia del género en España, a pesar de todos estos obstáculos.

${ }^{4}$ No es nuestra intención presentar aquí un resumen de la obra, pero sí consideramos necesario resaltar aquellos elementos que destacan por su goticismo; para ello hemos de hacer referencia a determinados aspectos del argumento. 
se inicia gracias a las artimañas de la joven, que decide arrebatarle el amado a su amiga doña Marcela. Tales tretas ya comienzan a definir a esta mujer, que actúa resueltamente y no renuncia a conseguir su objeto de deseo.

Sin embargo, don Artal, su pretendiente, desbarata el idilio con la ayuda de la criada Dorotea, mediante una maquinación que hace creer a don García que doña Clara no lo ama. La joven no comprende el rechazo de su enamorado, hasta descubrir el embuste, y aunque intenta recuperarlo, no lo consigue, puesto que en el ínterin él ha regresado junto a doña Marcela y van a casarse. La frustración de doña Clara, alimentada por la conciencia de injusticia, va creciendo en su interior y transformándose en crueldad y ansias de venganza.

Aquí es cuando comienzan a asomar los elementos góticos, cuyo punto de partida coincide con el momento en que doña Clara acude a una hechicera "que tenía fama de ser la mayor hechicera de la Europa, á quien declaró su agravio, ofreciéndole buena paga si la vengaba con muerte de don Artal, y Teodora" (Castillo Solórzano 1909 [1626], p. 162$)^{5}$. La mujer, que no se describe y que no posee más papel en la trama que ser la artífice, sin nombre y sin rostro, de la revancha de la joven protagonista, "codiciosa de la buena paga que doña Clara la ofrecía, la prometió dejarla vengada muy á su satisfacción. Y así la pidió que mirase qué género de muerte quería que les diese, si breve ó dilatada" ( $i d$. .). Nada se aclara acerca de las capacidades de la mágica ni de los medios concretos que aplica para lograr sus propósitos $^{6}$; solamente se especifica que, teniendo en su poder dos prendas de las potenciales víctimas, hizo sobre ellas sus conjuros (p. 163). Lo que sí sabemos es que en ningún momento se pone en duda la eficacia de sus artes. Así pues, ante las alternativas que se le ofrecen, doña Clara solicita que el final de sus enemigos sea dilatado, y así lo cumple la hechicera: "dentro de cuatro días los dos cayeron enfermos una tarde, á una misma hora. Y por espacio de un mes se les fué apurando la virtud, de tal modo que vinieron á perder las vidas, casi hechos unos esqueletos sin entender los médicos su mal” (p. 163).

Tras un mes de enfermedad, fallecen tanto don Artal como Teodora. Poco tiempo antes, había muerto también el padre de doña Clara, con lo cual queda dueña absoluta de sí misma y de sus bienes. Sólo se consuela de su dolor cuando descubre que sus oponentes han

${ }^{5}$ Todas las citas de La cruel aragonesa proceden de la edición de 1909, por lo que, en adelante, únicamente se registrará entre paréntesis la página correspondiente a cada pasaje, aludido o reproducido. También se ha consultado la edición de las Jornadas alegres de 1626 y la más moderna, incluida en la antología de GonZÁlez DE VEGA (2015). Esta última, sin embargo, simplifica algunas frases y otras directamente las elimina, por lo que nos parece más fiable la de 1909. No existe, a día de hoy, ninguna edición crítica de la obra.

${ }^{6}$ Sí apunta el narrador que estas mágicas se mueven por interés, sin reparar en la ofensa que hacen a Dios (p. 162). 
recibido su merecido. Lo que sucede a continuación supone la culminación del proceso de transformación de doña Clara en un monstruo:

Mas el día que vió muerto a don Artal, y Teodora, como estaba tan vivo en ella el deseo de la venganza se consoló de la pérdida de su padre; infundiéndosele en su femenil sujeto un afecto tan cruel que la hizo degenerar de su primero ser, manifestándolo en la misma noche que enterraron á los dos difuntos, con una acción la más inhumana que en historias antiguas y modernas se ha visto escrita.

De la iglesia donde don Artal y Teodora se enterraron, hizo aquella noche llamar al sacristán secretamente, á quien ofreció una buena dádiva, por que á la media noche le abriese la iglesia, y juntamente la bóveda donde los dos estaban sepultados (pp. 163-164).

La crueldad de la joven eclosiona de tal manera que todo su ser se metamorfosea y se vuelve capaz de las más grandes atrocidades. El primer paso consiste en llegar hasta el lugar donde habían sepultado los cuerpos de ambos finados, y el momento propicio para ello es la media noche. Ya en la iglesia, el sacristán "encendió una hacha para alumbrarles: á la bajada de la bóveda...; y mostrándole entre otras la caja que depositaba el cuerpo del malogrado don Artal, la abrió la misma doña Clara, descubriéndose el difunto cuerpo" (p. 164). A ese cadáver dedica la joven unas desagradables palabras y unos actos que implican la profanación más abominable:

Esto decía al mismo tiempo que con un cuchillo que llevaba hacía pedazos el hábito del seráfico padre San Francisco, con que don Artal se había enterrado, y luego la mortaja. El sacristán temeroso de perder el donativo que esperaba, no osaba irle á la mano en lo que hacía, y la criada nueva en su privanza tampoco, y así la dieron lugar los dos para que abriese al difunto por la parte del pecho y estómago; y sin darla horror y asco lo que hacía, metió la mano por la herida, sacándole el helado corazón, al cual viéndole en sus manos, dijo:

-Este fué el archivo que guardó tantos ofensivos pensamientos; que forjó tantas ignominias contra sus prójimos, y la aljaba de donde salían tantas ofensas para todos. Entre los cuales salió de esta aleve oficina, el rayo que desacreditó mi honor para que don García no fuere mi esposo.

Decía esto con tanta cólera y pasión, que parecía despedir centellas por los ojos; y de cuando en cuando, rabiosa, como la leona despojada de sus recién nacidos hijos, daba bocados en el difunto corazón... No bien satisfecha con lo que había hecho, quiso hacer otro tanto con el cuerpo de Teodora (pp. 164-165).

Hallamos, como se puede observar, el motivo medieval del corazón arrancado y comido, como también resalta Zerari (2014, p. 251) ${ }^{7}$.

${ }^{7}$ El único trabajo acerca de La cruel aragonesa es el de ZERARI 2014, de ahí que hagamos referencia a él en varias ocasiones. No pretendemos abusar de 
Sin embargo, es Isabel de Riquer (2007) quien analiza en profundidad esta leyenda, en la que también se centra Marín Pina (2012). Vemos que siempre se repite de la misma manera: la dama recibe o ingiere el corazón del amante, por obra del personaje negativo de la trama, y lo hace de forma involuntaria; de hecho, al enterarse de lo sucedido, desfallece, o bien termina suicidándose. Se trata de un acto de crueldad de quien se opone a la relación de los enamorados. En esta ocasión, no obstante, la mujer que devora el corazón actúa de forma voluntaria y cruenta, con plena conciencia de lo que está haciendo, para que su venganza sea más palpable luego del acto precedente de profanación del cadáver. De la misma manera, Zerari (2014, p. 251) se refiere a las historias trágicas de Bandello ${ }^{8}$; en concreto, hemos de fijarnos en la novena novela, en la que aparece también el corazón comido: "De la crueldad de Pandora, dama milanesa, contra el propio fruto de su vientre, por verse desamparada de quien le avía engendrado". En este texto, la dama protagonista se venga de su amante, Parthenopeo, por haberla dejado sola y embarazada $^{9}$. Intenta abortar y, como no lo consigue, malpare y sacrifica al niño; incluso lo despedaza a dentelladas y toma entre sus dientes el pequeño corazón, órgano que da a comer finalmente a un mastín. Es evidente que la crueldad de Pandora supera a la de doña Clara ${ }^{10}$.

Volvamos al texto. Cuando el sacristán comienza a presenciar los abominables despropósitos de doña Clara, la increpa y le advierte que no dejará que siga adelante con semejantes actos de perversión, oposición que sólo acarrea su propia muerte a manos de la enajenada muchacha. No habrá consecuencias inmediatas para doña Clara,

esta fuente, pero es inevitable aludir a ella ante la falta de otros estudios sobre la obra.

8 Otra de las fuentes del relato, que no tiene que ver ya con el motivo del corazón devorado, es una novela de Sansovino (GIORGI 2012, pp. 81-82; FERNÁNDEZ RoDríguez 2016, pp. 223-224), a la cual habría tenido acceso Castillo Solórzano a través de Cento novelle scelte da' piu nobili scrittori della lingua volgare di M. Francesco Sansovino (1561). En La cruel aragonesa se encontrarían reminiscencias de la novela VI de la IX jornada (así numerada a partir de la edición de 1562, como afirma FERNÁNDEZ RoDRíGuEz 2016, p. 223, n. 25). En esta novela, Lucretia será la mujer vengativa, al saber que su amado y amante, Paolo, la ha olvidado por otra joven, Fioretta, a quien termina envenenando luego de tramar meticulosamente la implacable revancha. Paolo, destrozado, no encuentra otra manera de devolver el golpe a su antiguo amor que suicidándose, para causarle todo el dolor que ella le ha provocado al asesinar a Fioretta. El modo retorcido del proceder de Lucretia se puede observar cuando finge ante Paolo que acepta su nueva relación, que no le guarda ningún rencor y que quiere que confíe en ella y que siga visitándola.

9 También aquí Pandora requiere los servicios de una hechicera para atraer al amado, pero las hechicerías no dan resultado (f. 243v).

${ }^{10}$ Pero hay varios elementos presentes en esta novela corta del siglo XVII ausentes en BANDELLO (1603), como la oscuridad o lo preternatural efectivo, y con una funcionalidad manifiesta, como la bóveda a la que desciende doña Clara para tener acceso a los cadáveres y los espectros cuyas voces atormentan a la asesina. 
pero a partir de ese momento se ve aquejada de una gran melancolía: "Todo esto nacía de haber oído en su aposento todas las noches, después que se hizo la rigurosa crueldad en el cuerpo de don Artal y dado muerte al sacristán, unos dolorosos suspiros que no la dejaban dormir" (p. 168). Esto, sin embargo, no impide a la joven continuar cometiendo mayores agravios. El encuentro con don García reactiva su locura:

Y así volviendo á verse con la hechicera, la consultó su pena y prometió nuevo premio, si la vengaba de don García, recibiendo el daño su esposa, á quien él tanto estimaba. La experiencia de la buena paga por lo hecho, hicieron solícita en servirla á la impía maga y así la prometió darla gusto con mucho cuidado en lo que deseaba; fuese con esto á su posada, y con sus embustes ${ }^{11}$ y conjuros, invocando demonios hizo que dentro de seis días cayese doña Marcela mala en la cama, con los más intolerables y recios dolores en todos sus miembros que sujeto humano ha sufrido... Desta suerte pasó doña Marcela un mes, dejándola los intensos dolores hecha un cadáver, los cuales sufría la inocente señora con grande paciencia (pp. 171-172).

Tras el fallecimiento de su "amiga”, y ya casada con don Rodrigo, retoma la relación con su amado don García. Además, “quiso, pues, doña Clara conservar esta amistad con don García y que él no fuese señor de su voluntad, y así, acudiendo a los ilícitos remedios de la hechicera, la pidió hiciese de modo que don García la quisiese con grande extremo, sin divertirse con otra mujer" (p. 174). Así lo hace la malvada con sus "embustes diabólicos" (p. 175) ${ }^{12}$, de tal manera que el enamorado, ya fuera de sí, sólo encuentra dicha cuando se halla en presencia de la dama.

Este comportamiento temerario hace que el marido burlado descubra el adulterio y trame su venganza. El desgraciado final de la cruel aragonesa viene precedido de las voces que han estado acompañándola desde que cometió su primer crimen. Después, se apaga la lamparilla "con la violencia de un recio soplo que oyeron" (p. 180); posteriormente:

11 A pesar de que se usa la palabra embustes, lo cual supone una forma de desacreditar los actos de la hechicera, la eficacia es innegable y el narrador no la pone en duda en ningún momento.

12 Vuelve a aparecer el término embustes; igualmente, se llama a la hechicera "fraudulenta mujer" (p. 175), aunque a continuación se previene al lector sobre estas mágicas y se recomienda a la justicia que limpie la sociedad de ellas, pues "no hay con sus embustes diabólicos vida segura, voluntad sin violencia, ni venganza sin efecto" (p. 175). De este modo, aunque se usen tales palabras y expresiones para referirse a quienes tienen por oficio la hechicería, se les adjudica toda clase de males, y si son fraudulentas o embusteras es porque engañan a sus clientes acercándolos al diablo, y no por ser unas estafadoras cuyas acciones no surten el efecto deseado. 
En esto cesaron por un rato los dolorosos suspiros, y doña Clara quiso entretener á su galán de aquel cuidado, y para ponerle en más obligación, para que la tuviese amor con más veras que hasta allí; le dió cuenta de cómo ella había sido la causa de la muerte de don Artal y Teodora, su criada, vengándose de la ofensa que los dos la habían hecho, levantándola aquel falso testimonio de que la había gozado, y últimamente le hizo relación de la inaudita crueldad que hizo en la bóveda con el difunto cuerpo de don Artal, por mitigar la cólera que contra él había concebido.

$\mathrm{Al}$ tiempo que estaba diciendo esto á don García, teniéndole absorto lo que la escuchaba, se oyó una dolorosa y dilatada voz al cabo de la pieza en que estaban, con que don García y su dama se quedaron helados de temor; y erizándoseles los cabellos se estuvieron inmóviles, sin poder hablarse palabra el uno al otro. Prosiguió con otras dos voces, diciendo á la tercera:

-Presto llegará el riguroso castigo que mereces.

Apenas se oyó esto, cuando al mismo tiempo abrieron la puerta de aquel aposento, y por ella entró don Rodrigo (pp. 180-181).

Don García consigue escapar, pero doña Clara es herida. Y al no poder el marido ofendido vengarse del amante, "redundó su enojo en la imprudente doña Clara, á quien quitó luego la vida á puñaladas $^{13}$, sin darla lugar siquiera a arrepentirse de sus culpas, digno castigo de sus rigurosas crueldades" (p. 182) ${ }^{14}$. Don García será el único superviviente de este triángulo amoroso -y tomará el hábito-, puesto que don Rodrigo fallece por una grave e insondable enfermedad.

El propósito moral del relato no puede ponerse en duda ${ }^{15}$. Hay un castigo muy evidente tanto para doña Clara como para don Rodrigo, quien también fallece -si bien por causas naturales- sin poder completar su venganza. Don García no es condenado porque en realidad es un títere en las manos de doña Clara. Tampoco se comenta

13 Grouzis Demory y López del Barrio (2014, p. 17) inciden en el hecho de que don Rodrigo es el único marido que mata a puñaladas a su esposa en la obra de Castillo Solórzano.

${ }^{14}$ La finalidad moral del relato es evidente. La crueldad de doña Clara se castiga con la violencia que el marido ejerce sobre ella, y se considera un acto ejemplar, pues el monstruo no podía quedar sin punición, menos tratándose de un monstruo femenino, aún más transgresor precisamente por las características que comprende.

15 López SANTos (2010, pp. 149-177) explica las características propias de nuestra literatura gótica y destaca las conductas ejemplarizantes y las lecciones morales, que se resaltan especialmente en los prólogos de los textos, con el fin de superar la censura. En cierto modo, se continúa la tendencia del siglo XVII en este aspecto. Sin embargo, RAfAel Llopis (2013, pp. 28-30) ahonda en la idea de que la literatura de terror tiene la finalidad de causar miedo - un temor que hace disfrutar al lector-; su objetivo, pues, no es satirizar ni moralizar. Por ello mismo, para Llopis (p. 28) las muestras anteriores al siglo Xviı pueden colindar con el terror, pero han de tomarse sobre todo como antecedentes, aunque habría algún texto excepcional que entraría de lleno en el género -esto se da básicamente por la presencia de un miedo moralizante. 
nada acerca de la suerte de la hechicera, pues se limita a cumplir un encargo, por lo que la culpa se transfiere a quien solicita sus servicios y no a la maga en sí, que es la que practica la magia negra, como evidencia el relato, totalmente efectiva.

\section{LA CRUEL ARAGONESA COMO ANTECEDENTE}

DE LA LITERATURA GÓTICA

Comenzaremos este apartado haciendo referencia a lo expuesto hasta ahora sobre este texto, de mano básicamente de Zerari (2014) y alguna otra mención superficial hallada en estudios como el de Grouzis Demory y López del Barrio (2014).

El conjunto de los elementos más monstruosos o macabros que podemos hallar en este relato es lo que impulsa a Zerari a decir que el texto "forma parte de la vertiente grave del corpus cortesano" (2014, p. 244), junto con los Desengaños de María de Zayas y los "sucesos trágicos" de las Calenturas de amor de Luis de Guevara, "entre otras obras de tinte oscuro", aunque asegura que las Jornadas de Castillo Solórzano no presentan la gravedad trágica de los novellieri y los novelistas franceses, lo cual avalamos tras la investigación que hemos llevado a cabo. Esta experta profundiza en el carácter monstruoso del personaje principal, y afirma: "No sería de extrañar que, además de horrorizados, los lectores del Siglo de Oro quedaran un tanto turbados ante las sugestivas imágenes generadas por la evocación de una feminidad tan intensa como transgresora” (p. 245) ${ }^{16}$, cuyo motor sería en un principio la curiosidad ${ }^{17}$, la cual generaría un amor fruto de la envidia y el orgullo, que desemboca en el dolor antes de transformarse en una pasión aniquiladora. Es la venganza, que deriva de dicha fuerza destructora, la que otorga a la novela corta un tinte sombrío, tomando como núcleo la figura de doña Clara y su animalización en la escena en que arranca y da bocados en el corazón de don Artal. Por ello, Zerari la ve como arpía, dama monstruo cuyo "peso textual

16 Para Grouzis Demory y López del Barrio (2014, p. 6), la crueldad de doña Clara es tan descomedida que sus actos violentos restan verosimilitud a la historia. La monstruosidad del personaje y su animalización generarían incredulidad. No estamos de acuerdo con esta afirmación, en la medida en que esa exageración se lleva mucho más al límite en los textos góticos, y nos hallamos, en el caso de La cruel aragonesa, frente a un antecedente de este tipo de literatura. Si nos fijamos especialmente en una de las obras (traducción-adaptación) más representativas de nuestras letras góticas, la Galería fúnebre de Pérez Zaragoza (1831), veremos que se lleva al límite de un modo mucho más acentuado lo expuesto en la novela corta de Castillo Solórzano, tanto en referencia a la monstruosidad de los personajes como en las venganzas sangrientas.

17 Castillo (2010, pp. 1-35) otorga una gran relevancia a la curiosidad como motor que conduce al horror durante el Barroco. 
es de carácter intertextual, por ser una figura no muy hondamente caracterizada, mas repleta del tenebroso carisma de toda una tradición artístico-literaria muy atenta a la feminidad, a la par que muy misógina" (p. 251) ${ }^{18}$. Zerari termina esa parte de su estudio aduciendo que este relato

Constituye, pues, una atrayente novela de oscura tonalidad. A pesar de su propósito moralizador..., el texto de Castillo Solórzano se presenta como una entretenida y atrevida historia de eros y thanatos llena de espectacular violencia y de erotismo intertextual. De hecho, si la novelita logra destacarse e incluso lucirse, es por medio de la fábrica de un monstruo mujer: una cruel del siglo xvir... La cruel doña Clara se presenta como una impresionante figura intermedia entre la furiosa trágica y la diabólica romántica y posromántica (p. 253) ${ }^{19}$.

Si nos hemos detenido tanto en esta aportación de Zerari, es porque no hay otro trabajo que estudie de modo tan particular, y exclusivamente, La cruel aragonesa. Por tanto, ha de servirnos como punto de partida para exponer las tesis que constituyen el núcleo del presente artículo. Una vez desgranados los principales argumentos que esta experta presenta, no es necesario volver sobre las mismas cuestiones que ella trabaja. Avalamos su planteamiento y sus afirmaciones, y a partir de ellos elaboramos nuestra aportación.

Ciertamente, doña Clara se perfila como un monstruo femenino. No posee una profundidad psicológica que la ponga al nivel de la Pandora de Bandello o de la Lucretia de Sansovino, pero el relato, en general, posee ciertos elementos que lo llevan a destacar sobre otras narraciones de la época. Zerari resalta básicamente la paulatina transformación de la protagonista en un engendro, desde un punto de vista moral, que hace gala de una crueldad desmesurada. Esta característica también aparece bien representada en la figura de Pandora, que es capaz de despedazar el fruto de su propio vientre como revancha contra su amante, al igual que Medea.

18 Aunque de modo mucho más superficial, Grouzis Demory y López DeL BARRIO (2014, pp. 13-14) también reparan en estos aspectos atinentes a la protagonista.

${ }^{19}$ Al hilo de esta afirmación, cabe recordar lo que sostiene García AdÁnez (2004, p. 118): "España es un país rico en motivos, leyendas y tradiciones siniestras", y lo dice al justificar que en España se dio una presencia indiscutible de lo macabro y sombrío, que ella asocia a la muerte (p. 119), a pesar de que, posteriormente, el Romanticismo que se desarrolló fue superficial (p. 117). Este hecho no se debió, por tanto (aunque esta experta hable de Romanticismo, también podemos aplicar sus aseveraciones a lo gótico, anterior al movimiento que ella estudia), a la ausencia de un sustrato terrorífico, sino a otros factores en los que no vamos a profundizar aquí. La cruel aragonesa forma parte de esa tradición. 
En La cruel aragonesa, a esa barbarie se unen otros aspectos de interés. El primero es el recurso de la hechicería ${ }^{20}$. Si bien su presencia no aporta oscuridad al texto, pues no asistimos a sus prácticas ni se incide en la figura que la ejerce, en el argumento se introduce la magia negra ${ }^{21}$. De hecho, en la obra se explicita que la hechicera alcanza sus propósitos (o, mejor dicho, los de su cliente) "con sus conjuros, invocando demonios" (p. 171). De esta manera, uno de los núcleos del terror para H.P. Lovecraft destaca especialmente en el relato, pues afirma: "El terror cósmico... fue, sin duda, un rasgo destacado de la rebuscada magia ceremonial, con sus rituales de invocación de demonios y espectros" (2010, p. 33). Se trata, además, de una acción efectiva, de la que no se duda en ningún momento y que no supone un choque con la realidad del lector, y ésa sería una de las características más genuinas de los antecedentes del género de terror, pues la creencia en lo preternatural forma parte del horizonte de expectativas del lector y se opone, por tanto, a lo que diría Todorov (1980, p. 68) acerca de la función tautológica de lo fantástico: que no tendría una realidad exterior al lenguaje. No se percibe escepticismo alguno, cosa que sí es habitual en las distintas muestras de la literatura gótica de los siglos XVIII y XIX, aunque es sobre todo el punto de vista del lector el que se transforma durante estas centurias.

El segundo es el pasaje del descenso a la bóveda, de noche (lo cual remite a los corredores y pasadizos que pueblan los castillos y mansiones propios de las narraciones de horror) ${ }^{22}$, con el consiguiente descubrimiento de las tumbas (lo cual supone la presencia de lo macabro y funerario $)^{23}$, su profanación, el ensañamiento con el cadáver de don Artal, el acto de devorar el corazón (que acerca a doña Clara a la antropofagia propia de las brujas $)^{24}$ y el asesinato a san-

20 También Pandora recurre a ella con una finalidad amorosa, pero no da resultado y no se mencionan prácticas de este tipo en más ocasiones. La hechicería, por tanto, no posee función alguna en el relato.

${ }^{21}$ Dada la falta de espacio para entrar en cuestiones de nomenclatura mágica, remitimos al capítulo de Montaner y LARA (2014), en el que se aportan las claves de la diferenciación entre magia, hechicería y brujería, e igualmente, entre magia naturaly magia diabólica (esta última se identificaría con la magia negra, pues implica la invocación de demonios). Por lo demás, es interesante ver que para Martínez de Mingo (2004, p. 112), la magia negra es un elemento fundamental en la literatura de terror.

${ }^{22}$ Sería aquí muy importante el escenario (que se acerca al destacado por López SANTOS 2010a, cuando habla del cronotopo de la literatura gótica), aunque la ambientación y la riqueza de detalles no es comparable con la que se alcanza en siglos posteriores.

${ }^{23}$ Glendinning (1994) insiste en el gusto de lo funeral y macabro a partir del siglo XviII, aunque es evidente que, en nuestras letras barrocas, esa atracción por lo mortuorio está muy presente, como bien demuestra CASTILlo (2010) a lo largo de su estudio. También López SANTos (2010, p. 100) menciona el gusto por lo macabro en las letras góticas, que vendría de lejos y, por tanto, del Barroco.

${ }^{24}$ Este monstruo femenino nos recuerda en algún momento a las terribles brujas, cuyos actos vendrían muy bien ejemplificados en las dos relaciones de sucesos 
gre fría del sacristán, así como la amenaza proferida contra la pobre sirvienta que acompaña a esta homicida.

El tercero tiene que ver con las voces espectrales que atormentan incansablemente a doña Clara y que le anuncian, justo antes de que suceda, que se acerca su castigo final ${ }^{25}$. Este augurio de lo que está por venir, mediante susurros fantasmales, aporta una dosis de terror complementaria al fragmento en el que don Rodrigo acecha a los amantes y se toma la justicia por propia mano, quitándole con fiereza la vida a su adúltera esposa.

Si comparamos La cruel aragonesa con otros textos que también pueden considerarse precedentes de las letras góticas ${ }^{26}$, no en su totalidad, pero sí en alguno de sus pasajes -nos referimos a la literatura de terror sobrenatural con ingredientes mágicos-, como la Silva curiosa, de Julián de Medrano (1583) ${ }^{27}$, La fuerza del desengaño, en Sucesos y prodigios de amor, de Juan Pérez de Montalbán (1624), Varia fortuna del soldado Píndaro, de Gonzalo de Céspedes y Meneses (1626), La fuerza del amor, de María de Zayas, una de sus Novelas amorosas y ejemplares (1637), el suceso primero, Qué son dueñas, de las Intercadencias de la calentura de amor de Luis de Guevara (1685), nos damos cuenta de que, si bien todos estos textos aportan ingredientes fundamentales muy dignos de ser analizados, esta novela corta de Castillo Solórzano reúne varios elementos que, armonizados, le otorgan una especial relevancia en el estudio que estamos llevando a cabo.

En la Silva curiosa de Julián de Medrano, concretamente en los pasajes importantes desde el punto de vista terrorífico, el tema amoroso no alcanza relevancia. Tanto el género como la forma de concertar los motivos que nos interesan alejan esta obra de la que motiva nuestro estudio. Sí se incide mucho en lo siniestro y macabro, en las tumbas, cadáveres, incluso espectros, e igualmente comparece la magia negra, aunque no de forma que permita trazar demasiados

acerca del Auto de Fe de Logroño de 1610, editadas ambas en 1611, una de ellas publicada por don Juan de Mongastón en Logroño y la otra por Juan Bautista Varesio en Burgos. En ambas relaciones se hace hincapié en el vampirismo y la antropofagia de brujos y brujas, y en los homicidios que llevaban a cabo. Al respecto, se puede consultar LARA Alberola 2017 y 2017a.

25 El fantasma es una figura central en las letras góticas y fantásticas, tal y como atestiguan RoAs 2000, p. 21; López SAnTos 2008a, pp. 192-197; y SÁnChez-Verdejo 2013 , p. 28.

${ }_{26}$ Algunos de estos textos los menciona Aldana (2017, pp. 8-9), quien, por lo demás, no hace referencia a La cruel aragonesa; lo mismo sucede en CASTILLo 2010, caps. 2 y 3. López SAntos (2010, p. 100), en cambio, no olvida a Pérez de Montalbán o María de Zayas, para justificar una atracción por lo macabro anterior al siglo XviII. De hecho, para esta especialista, hubo géneros especialmente significativos de cara al desarrollo posterior de la literatura de terror; por ejemplo, el cuento literario, maravilloso y de crímenes.

27 Un temprano antecedente de gran interés, en relación con la presencia de la nigromancia y brujería, y cómo ambas se conjugan con lo mortuorio. 
paralelismos entre ambos textos. La crueldad y el homicidio, por ejemplo, se hallan ausentes. Por ello, no nos detendremos más en esta muestra.

La fuerza del desengaño de Juan Pérez de Montalbán es una narración sentimental del estilo de La cruel aragonesa, por lo que los puntos en común pueden ser más evidentes, desde el triángulo amoroso entre Narcisa, Valerio y Teodoro, hasta la gótica escena en que Lucrecia, amante despechada de Teodoro, intenta conseguir el corazón del difunto Andronio (asesinado por aquél) para dar a beber al esquivo amado sus cenizas mezcladas con vino, con la esperanza de recuperarlo. Encontramos, en efecto, otro caso de hechicería. Lucrecia va en busca de este ingrediente impulsada por una hechicera a la que ha recurrido, pero las artes mágicas a que iba destinado nunca llegan a ponerse en práctica -aunque son el resorte que permite el desarrollo del episodio oscuro y terrorífico. De hecho, el cadáver de Andronio impide que se concreten al levantarse de la tumba para increpar a la joven, que pronto se arrepiente de su comportamiento. Faltan aquí, con respecto a lo que podemos hallar en la novela corta de Castillo Solórzano, la funcionalidad de la hechicería y la crueldad monstruosa de doña Clara.

Es cierto, por lo demás, que el pasaje de la Varia fortuna del soldado Píndaro, en que el capitán Céspedes y don Francisco topan con una vieja que causa espanto, en medio de un bosque, de noche y durante una terrible tormenta, resulta francamente llamativo. La vieja es una hechicera que practica una potente magia amatoria-aunque su aspecto, el entorno en el que actúa, su capacidad para influir en el tiempo atmosférico y el uso de un muñeco de cera para conseguir su propósito llevan a pensar que podría ser catalogada más bien como una bruja-, y el hallazgo que hacen los protagonistas de cierto objeto que usa para sus artificios los pone en una situación de peligro -pero no hay asesinatos, como en La cruel aragonesa, ni profanación de cadáveres, ni crueldad alguna comparable con la de la muchacha zaragozana. Hay, además, un aspecto que destaca especialmente en el texto: al final de este episodio se deja muy en claro que todo lo sucedido sirve para aleccionar al personaje principal, quien se mostraba escéptico ante la posibilidad de esta clase de acontecimientos. Este tipo de episodios suele aparecer con mucha frecuencia en las posteriores letras de terror, pues lo sobrenatural irrumpe en los relatos cuando se ha dejado de creer en lo numinoso ${ }^{28}$.

La fuerza del amor de María de Zayas interesa en la medida en que, nuevamente, es el desamor el que conduce a la mujer a buscar remedio a sus males en la hechicería. Nunca ejecuta ella misma los

28 Para Llopis (2013, pp. 28-30), el escepticismo en algún personaje o punto del relato -en relación con los antecedentes- lo acerca de forma más acentuada al género de terror. 
hechizos, sino que se apoya en otras que son diestras en estas artes. Aquí, como en el caso de Juan Pérez de Montalbán, el acto mágico no llega a concretarse, pero la búsqueda de los elementos necesarios -o supuestamente necesarios, pues muchas veces se tilda a las hechiceras de embusteras- desemboca en el episodio que nos permite considerar estos textos como antecedentes de las letras góticas. Por ello termina Laura en un humilladero donde se encuentran los cuerpos de los ahorcados, pues ha de ser ella misma quien se provea de barbas, cabellos y dientes de estos ajusticiados -sólo así podrá volver a atraer a su marido, quien, además de tener una amante, la maltrata. Esta situación tiene lugar durante una noche especialmente tenebrosa, en la que sale embozada y sola para terminar paseándose entre finados. Sin embargo, no está presente la fuerza de doña Clara, su carácter vengativo, su falta de escrúpulos a la hora de optar no por la magia amatoria, sino por la magia negra, para hacer morir a quienes la han ofendido. Laura no tiene contacto directo, finalmente, con los ahorcados, así que no hay profanación de cadáveres ni aplicación de violencia, en ellos o en algún otro personaje.

Para terminar con este breve repaso, comentaremos sucintamente Qué son dueñas, de Luis de Guevara, ya que las relaciones amorosas también son clave, como en las narraciones anteriores, y la hechicería está presente en su dimensión de maleficio, puesto que, con sus ardides, la dueña Gómez no sólo ha terminado con el matrimonio de doña Engracia y don Blasco, sino que también está a punto de acabar con la vida de doña Luisa, prima de la protagonista, por medio de unos hechizos ${ }^{29}$. El pasaje cuyo ambiente invoca el espanto se intercala cuando don Ramiro, valedor de Engracia, regresa a Jaca y entre "negras nubes y horribles sombras" (2018 [1685], p. 256) topa con un bulto: la dueña moribunda, quien confiesa todos sus actos y desvela cómo doña Luisa puede recuperar la salud. Al amanecer, sin embargo, don Ramiro sólo ve la mula de la dueña Gómez revolcándose en su propia sangre y, cerca, otro lago de sangre con señales de que alguna persona ha estado tendida sobre él. Parece que se trata de un horrendo suceso que puede tener que ver con lo fantasmal, aunque no se dan más detalles. Gómez es la causante de todos los males de la historia, aunque no llega a la talla de doña Clara.

Vistas las razones de la elección de La cruel aragonesa para un estudio independiente del texto, trataremos a continuación todas las características que cumple la narración para poder, efectivamente, hablar de goticismo. En primer lugar, iremos mencionando cada uno de los requisitos aportados por Carnero (1993, pp. 525-527); en segundo, realizaremos las especificaciones necesarias con respecto al texto que nos ocupa:

${ }^{29}$ Entre los componentes se encuentran huesos de niños, plumas de aves raras y de mal agüero, y sogas de intestinos. 
1. Época preferentemente remota, abunda el medievalismo, aunque no es requisito imprescindible. En La cruel aragonesa el tiempo no se especifica, pero suele ser contemporáneo. Como ese pasado remoto no es cuestión indispensable, que este ítem no se cumpla no tiene demasiada importancia.

2. Lo terrorífico moral está representado por el tirano gótico, que practica sin pudor el asesinato, la tortura, los castigos corporales y los abusos sexuales. El tirano gótico, que por lo regular es quien atormenta a la protagonista del relato y le inflige daño, no está presente en esta novela corta, pues no se puede considerar a don Artal tal tirano. En todo caso, más bien habría que hablar de tirana en referencia a la figura de doña Clara, cuyo comportamiento revela tales características. Existe, podemos concluir, una tiranía de la joven aplicada en los personajes tanto de doña Marcela como, sobre todo, de don García. Pensemos, además, que doña Clara es homicida, directamente porque asesina al sacristán a sangre fría, e indirectamente en los casos de don Artal, Teodora y doña Marcela. No duda tampoco en descargar su ira en un cadáver, arrancarle el corazón y devorarlo. Por último, podemos considerar también que abusa de don García en cuanto que lo manipula por medio de hechizos, y él no es libre, al final del relato, para decidir si quiere o no pasar tiempo con la joven.

3. Los héroes o personajes positivos carecen de la fuerza o entidad de los malvados. Solución del conflicto por un "deus ex machina”. En efecto, los actantes positivos, como doña Marcela, resultan superficiales. Evidentemente, con toda su carga de crueldad, es doña Clara el personaje del relato con mayor fuerza. Don García, al igual que doña Marcela, también podría considerarse, a fin de cuentas, una figura positiva manipulada por doña Clara. Efectivamente, el desenlace no viene propiciado por este personaje, sino por el marido despechado que actúa. Don García se encuentra bajo un hechizo de amor y no vuelve en sí por sus propios medios; se libra de esta situación de control por la intervención de don Rodrigo, que es quien provoca el trágico final.

4. Entre los personajes secundarios aparecen los que se encuentran fuera de la ley o marginados. Aquí sólo las criadas podrían desempeñar un papel semejante, sobre todo si pensamos en Teodora, quien no da muestras de tener ningún reparo ante el engaño de que su señora es víctima. No obstante, no se puede considerar a las sirvientas como figuras marginadas o fuera de la ley. Por ello, este requisito no se cumple.

5. La heroína atribulada es el principal resorte de las emociones que pretende suscitar este tipo de literatura y sufre todo tipo de horrores. En este caso, no se puede hablar de heroína, sino, como ya hemos dicho, de tirana. No hay ninguna heroína atribulada en el texto, pero la gran víctima femenina de la historia sería, sin duda, doña Marcela.

6. Presencia de lo terrorífico natural: fuerzas desencadenadas de la naturaleza, cavernas, bosques... En el texto no hallamos tormentas ni 
tempestades, tampoco grutas ni zonas montañosas o bosques. Por lo tanto, no está presente lo terrorífico natural.

7. Presencia de lo terrorífico arquitectónico: castillos, conventos, ruinas, pasadizos, criptas, cementerios... Sí encontramos en La cruel aragonesa la bóveda (dentro de la iglesia) a la que desciende doña Clara en busca de los ataúdes, por lo que se puede hablar de cripta o cementerio.

8. Presencia de lo terrorífico sobrenatural: fantasmas, cadáveres, magia negra, intervención del diablo... Este requisito se cumple sobradamente, pues no sólo los fantasmas comparecen, al menos a través de los suspiros y gemidos; de la misma manera, se profana el cadáver de don Artal y está presente lo macabro y mortuorio. Por último, la magia constituye un núcleo fundamental, al provocar tres muertes y un comportamiento enajenado en don García por obra de los hechizos amatorios.

9. Presencia de lo terrorífico religioso: anticlericalismo, torturas, condenas, castigos, inquisición... No asistimos a una condena pública de doña Clara, pero sí al castigo, por la finalidad moral del relato. De ahí que don Rodrigo tienda una trampa a su esposa y a don García, y embista a puñaladas, con ensañamiento, a la adúltera. Eso sí, también don Rodrigo muere, aunque a causa de una enfermedad, y no puede dar caza a don García, el único que consigue escapar de la muerte.

En síntesis, se podría decir que de los nueve requisitos expuestos por Carnero se cumplen seis. Sin embargo, como el primero no se considera indispensable, en realidad serían seis de ocho -hay que tener en cuenta que el quinto no lo encontramos como tal, sino con variantes. Por lo tanto, existen suficientes elementos como para hablar de un marcado goticismo en la obra.

Pasemos a continuación a comprobar en qué medida se ajusta $L a$ cruel aragonesa a los parámetros marcados por López Santos (2008a) en relación con el argumento, los personajes, el narrador y las coordenadas espaciotemporales. Procederemos del mismo modo que en el caso anterior:

1. Argumento como sucesión de enigmas; todo elemento de la narración parece esconder algo, causalidad oculta, presencia de algo misterioso que se presenta como desconocido, ambigüedad con respecto a lo sobrenatural; escenografia de elementos espeluznantes; exploración del sentimiento del miedo. Dos grandes pilares temáticos: muerte (ahi estaría el fantasma) y dolor físico (asesinatos, torturas y agresiones) y moral (mediante temas prohibidos como el triángulo amoroso $)^{30}$. Como no estamos ante un texto que pertenezca al género gótico, no hallamos ni el misterio ni el enigma; tampoco la ambigüedad en cuanto al elemento sobrenatural; la escenografía está poco trabajada (se le presta más atención en otras obras precedentes que hemos mencionado más arriba), y causar miedo no es lo

${ }^{30}$ Olvida López SANTos (2008a, pp. 196-197) incluir en el dolor moral el uso de la magia negra. 
que pretende el relato. No obstante, sí están presentes los dos pilares temáticos, tanto la muerte como el dolor. La primera no solamente por las voces o gemidos espectrales que persiguen a doña Clara, sino también por los homicidios perpetrados y por su ensañamiento con el cuerpo de don Artal. El segundo, tanto en su vertiente física por los asesinatos y la tortura -que supone el lento consumirse de sus enemigos por acción de la magia-como en su dimensión moral, ya que se presentan dos triángulos amorosos, el de doña Marcela, don García y doña Clara, y el de doña Clara, don Rodrigo y don García, que termina con el castigo final del personaje principal, por adulterio y por todo el daño causado a otros. Añadiremos aquí el dolor o daño moral provocado por el hecho de recurrir a la magia demoníaca. Si bien es la hechicera quien arriesga personalmente su alma, doña Clara representa la intención.

2. Actores del relato (siempre fijos y estereotipados): el villano, verdadero protagonista de las novelas góticas (seres perturbados y satánicos, que rompen con los valores establecidos); la mujer fatal (perversa, dominante y atroz, se rinde a las maldades del mundo, su comportamiento afecta a la débil y angelical heroína); el caballero (apuesto galán que pretende la mano de la heroína, agraciado y virtuoso); la heroina (representante de todas las virtudes y bondades, suele aparecer en un segundo plano, expuesta a las maldades del auténtico protagonista, que es el villano). En esta novela corta, se podría decir que el villano y la mujer fatal se han conjugado para dar lugar a doña Clara, aunque también podríamos prescindir del villano y apostar únicamente por la mujer fatal, pues la joven cuenta perfectamente con las características de este tipo. El caballero, sin duda alguna, sería don García, quien no siempre se comporta como tal, dado que se deja seducir por doña Clara con facilidad y abandona a doña Marcela. La heroína, habida cuenta de que puede quedar en un segundo plano, en todo caso sería doña Marcela.

3. El narrador suele perfilarse como testigo de los hechos para dar credibilidad a la historia, pero no deja de ser un narrador omnisciente tradicional. Se muestra normalmente algo escéptico ante lo insólito del relato. El narrador de La cruel aragonesa, evidentemente, no se muestra como un testigo directo ni duda de lo expuesto por su carácter insólito -por la presencia de lo preternatural-, pues nos hallamos en la segunda década del siglo XviI. Eso sí, es omnisciente.

4. Coordenadas espaciotemporales: espacio terrorifico que posee gran entidad, lugares concretos como el castillo, el monasterio o la abadí; tiempo pasado remoto y oscuro, preferentemente medieval; tiempos internos a veces inconexos entre sí tiempo más bien psicológico. En esta obra, el espacio terrorífico se halla ausente como tal, con la fuerza y la relevancia que posee en las muestras representativas del género. Sin embargo, aunque no topamos con castillos, monasterios ni abadías, sí lo hacemos con la iglesia en la que se encuentra la cripta; el descenso a la 
bóveda sí cumple con estos principios, pero la descripción del escenario está ausente. El tiempo no es pasado, remoto, oscuro y mucho menos medieval, como ya advertíamos anteriormente, y hay un orden cronológico en la concatenación de sucesos que conducen al desenlace, por lo que este parámetro no se cumple.

En definitiva, podemos resaltar la presencia en el texto de los dos grandes pilares temáticos y de algunos de los personajes imprescindibles en la narrativa gótica, con sus variantes, claro está. En cuanto al espacio-tiempo, nos acercamos a uno de los escenarios góticos en el pasaje de la bóveda, nada más. Aun así, hay una cantidad suficiente de elementos como para hablar de goticismo.

Para terminar, sólo resta añadir un par de observaciones importantes que avalan el carácter terrorífico de la novela corta de Castillo Solórzano. La primera tiene que ver con la curiosidad a la que se refería Zerari (2014, p. 246) como resorte, que lleva a doña Clara a querer saber más sobre don García, y que tan importante es para Castillo (2010) a propósito del horror barroco. Este afán por saber lo precipita todo y es un factor que destaca en relación con lo terrorífico. La segunda se deriva de los pilares temáticos ya discutidos: se trata de la violencia, que tiene que ver, por supuesto, con el dolor físico; pero Martínez de Mingo (2004, p. 17) le otorga la suficiente entidad como para resaltarla nuevamente, dado que tal violencia comparece en varios momentos del relato, por parte de doña Clara y contra la propia joven.

\section{Conclusiones}

Tras el estudio planteado, podemos concluir que La cruel aragonesa, al igual que otros textos con los que la hemos puesto en relación, reúne ciertas características o requisitos de entre los marcados por dos especialistas de la talla de Guillermo Carnero y Miriam López Santos que permiten hablar de un goticismo indiscutible. Es más, se debería incluir entre los relatos que hemos dado en denominar pseudoterroríficos ${ }^{31}$, que presentan un número suficiente de elementos espeluznantes, pero no se pueden considerar integrantes del género. Las novelas cortas del siglo XVII ofrecen ejemplos de diferentes acercamientos al terror, si bien a veces solamente en algunos de sus pasajes. Si nos hemos concentrado en la historia protagonizada por la zaragozana doña Clara es, como ya hemos argumentado a lo largo de este trabajo, porque en el texto confluyen diversos elementos que

31 RAFAEL Llopis (2013, p. 288) habla de narraciones preterrorificas para referirse a aquellas en las que el terror tiene que ver con lo numinoso, con lo religioso. Para albergar esas otras obras que no se pueden encuadrar en dicha categoría, acuñamos la expresión "relatos pseudoterroríficos". 
no suelen aparecer de forma conjunta en otros relatos: la perversidad de la protagonista, que estalla a partir de un desengaño amoroso; el afán de venganza; el recurso a la hechicería con un fin homicida; la apertura de una tumba y el ataque furioso a un cadáver, con el consiguiente motivo del corazón comido -lo cual lleva a hablar indefectiblemente de violencia, aunque sea contra un finado-; la voluntad de dominio y manipulación del amado -por medio de la magia amatoria-; el horror de la sangrienta revancha perpetrada por don Rodrigo, y las voces espectrales.

La cruel aragonesa de Alonso de Castillo Solórzano es, por tanto, una narración que la crítica ha visto casi sistemáticamente con indiferencia. Sólo Zerari (2014) le ha prestado realmente atención al dedicarle todo un trabajo; el resto de menciones, dispersas en distintas investigaciones, son de carácter superficial y suelen centrarse en algún punto muy concreto. Y puesto que no hay una edición crítica de las Jornadas alegres, y al día de hoy sólo disponemos de la versión que recoge González de Vega (2015) en su antología, cuyos textos no están anotados, no contamos siquiera con una aproximación a la novela por parte de ningún editor. Quizás a ello se deba que la obra no se haya estudiado como merece.

Por lo demás, la obra resulta muy sugerente en lo que toca a la mujer monstruosa, cruel y despiadada, que aquí, más que víctima, es verdugo, aunque al final reciba el correspondiente y obligado castigo. Indudablemente, esa feminidad terrible despierta el interés, pero se debe advertir que la relevancia del relato es mucho mayor de lo que parece a simple vista y a la poca luz de las aportaciones de que disponemos en este momento. Doña Clara no es únicamente una mujer fiera y vengativa, un monstruo, sino también una figura que, a pesar de no presentar la profundidad de personajes como Pandora o Lucretia, refleja la fusión entre el villano gótico y la mujer fatal de la posterior literatura de terror. La cruel aragonesa se adelanta así a su tiempo. No es la única novela corta que lo hace, pero sí la única que presenta esta combinación tan genuina de ingredientes góticos. Por todas estas razones, se perfila como una obra que habría que desempolvar para estudiarla más concienzudamente y para restituirle el valor que merece.

\section{REFERENCIAS}

Aldana Reyes, Xavier 2017. Spanish gothic. National identity, collaboration and cultural adaptation, Palgrave Macmillan, London.

Bandello, Matteo 1603. Historias trágicas exemplares: sacadas del Bandello Verones nueuamente traduzidas de las que en lengua francesa adornaron Pierres Bouistan y Francisco Belleforest, contiénense en este libro catorze historias notables, repartidas por 
capitulos, por Alonso Ayala (por los herederos de Santo Domingo), a costa de Miguel Martínez, Valladolid.

CARnero, Guillermo 1983. La cara oscura del siglo de las luces, Cátedra, Madrid.

Carnero, Guillermo 1993. "La holandesa de Gaspar Zavala y Zamora y la literatura gótica del xviII español”, en Homenaje al profesor José Fradejas Lebrero. Eds. Antonio Lorente, José Nicolás Romera y Ana María Freire, Universidad Nacional de Educación a Distancia, Madrid, pp. 517-540.

Castillo, David R. 2010. Baroque horrors. Roots of the fantastic in the age of curiosities, University of Michigan, Michigan; doi: 10.3998/mpub.1125577.

Castillo Solórzano, Alonso de 1909 [1626]. La cruel aragonesa, en Jornadas alegres, Librería de los Bibliófilos Españoles, Madrid, pp. 129-186.

Castillo Solórzano, Alonso de 2015 [1626]. La cruel aragonesa, en El demonio meridiano: cuentos fantásticos y de terror en la España del Antiguo Régimen. Ed. Gerardo González de Vega, Miraguano, Madrid, pp. 322-338.

Céspedes y Meneses, Gonzalo de 1975 [1626]. Varia fortuna del soldado Píndaro. Ed. Arsenio Pacheco, Espasa-Calpe, Madrid.

Díez de Revenga, Francisco 2006. "Literatura española de terror: leyendo algunos relatos breves verdaderamente estremecedores", Verba Hispanica, 14, 1, pp. 77-93; doi: 10.4312/vh.14.1.77-93.

Fernández Rodríguez, Daniel 2016. "La influencia de las novelas de Girolamo Parabosco (pasando por Sansovino) en la literatura española del Siglo de Oro”, Estudios Románicos, 25, pp. 217-228, en https://revistas.um.es/estudiosromani$\cos /$ article/view/274571 [consultado el $1^{\circ}$ de diciembre de 2018].

Ferreras, José Ignacio 1973. Los orígenes de la novela decimonónica (1800-1830), Madrid, Taurus.

Ferreras, José Ignacio 1991. "La novela de terror en la España del siglo Xix", en El relato fantástico en España e Hispanoamérica. Ed. Enriqueta Morillas, Sociedad Estatal Quinto Centenario, Madrid, pp. 189-196.

García AdÁnEZ, IsABel 2004. "Los espacios de lo siniestro: paralelismos y contrastes en la literatura de terror del Romanticismo alemán y español", Estudios Filológicos Alemanes: Revista del Grupo de Investigación de Filología Alemana, 6, pp. 117-136.

Giorgi, Givlia 2012. "Novelar muy a imitación de lo de Italia. Castillo Solórzano, lector de Francesco Sansovino”, en Novela corta y teatro en el Barroco español (1613-1685). Studia in honorem Prof. Anthony Close. Eds. Rafael Bonilla, José Ramón Trujillo y Begoña Rodríguez, Sial Ediciones, Madrid, pp. 77-85.

GlendinNing, Nigel 1994. "Lo gótico, lo funeral y lo macabro en la cultura española y europea del siglo xviII", Anales de Literatura Española, 10, pp. 101-115, en http:/ / www.cervantesvirtual.com/obra/lo-gotico-lo-funeral-y-lo-macabro-en-lacultura-espanola-y-europea-del-siglo-xviii/ [consultado el 2 de octubre de 2018].

GonZÁlez de Vega, Gerardo 2015. El demonio meridiano: cuentos fantásticos y de terror en la España del Antiguo Régimen, Miraguano, Madrid.

Grouzis Demory, Christelle y Eva López del Barrio 2014. "Entre el cortejo y la violencia; amor, honor e infamia en la novela corta barroca. Los casos de María de Zayas y Alonso Castillo Solórzano”, Lejana. Revista Crítica de Narrativa Breve, 7, pp. 1-22, en https://edit.elte.hu/xmlui/handle/10831/33626 [consultado el 10 de noviembre de 2018]; doi: 10.24029/lejana.2014.7.

Guevara, Luis De 2018 [1685]. Qué son dueñas, en Intercadencias de la calentura de amor. Ed. Enrique Suárez Figaredo, Textos Lemir, 22, pp. 245-263, en http://parnaseo.uv.es/Lemir/Revista/Revista22/Textos/2_Calentura_de_Amor.pdf [consultado el 20 de noviembre de 2018].

Lara Alberola, Eva 2017. "El panfleto de don Juan de Mongastón sobre las brujas de Zugarramurdi (Auto de Fe de Logroño de 1610), editado en 1611”, RILCE: Revista de Filología Hispánica, 33, 1, pp. 259-282; doi: 10.15581/008.33.1.259-82. 
Lara Alberola, Eva 2017a. "Los ejemplos sobre brujería en las relaciones del Auto de Fe de Logroño de 1610 editadas por Mongastón y Varesio: estudio comparativo", Revista de Humanidades, 30, pp. 43-74; doi: 10.5944/rdh.30.2017.18202.

Lara Alberola, Eva 2021. "El relato terrorífico de las brujas. Del Malleus Maleficarum a la literatura de horror sobrenatural", en Magia y brujería: tradiciones literarias y culturales entre España y América. Eds. Gerardo Fernández Juárez, Francisco Miguel Gil García y José Manuel Pedrosa Bartolomé, Mitáforas Editorial-Universidad de Alcalá-Universidad de Castilla La Mancha-Abya Yala, Madrid-Castilla la Mancha-Quito [en prensa].

López Santos, Miriam 2008. "La novela gótica, sus mitos y la nueva literatura española”, en I Congreso Internacional de Literatura y Cultura Españolas Contemporáneas, Universidad Nacional de La Plata-Facultad de Humanidades y Ciencias de la Educación-Centro de Estudios de Teoría y Crítica Literaria, La Plata, pp. 1-12, en https://www.aacademica.org/000-095/63.pdf [consultado el 5 de febrero de 2018].

López Santos, Miriam 2008a. "Teoría de la novela gótica”, Estudios Humanísticos. Filología, 30, pp. 187-210, en http://revpubli.unileon.es/index.php/EEHHFilologia/article/view/2840/2017 [consultado el 17 de noviembre de 2018]; doi: 10.18002/ehf.v0i30.2840.

López Santos, Miriam 2010. La novela gótica en España (1788-1833), Editorial Academia del Hispanismo, Vigo.

López Santos, Miriam 2010a. "Ampliación de los horizontes cronotópicos de la novela gótica”, Revista Signa, 19, pp. 273-292, en http://revistas.uned.es/index. $\mathrm{php} /$ signa/article/view/6237/5970 [consultado el 19 de noviembre de 2018].

Lovecraft, Howard Phillips 2010 [1927]. El horror sobrenatural en la literatura y otros escritos teóricos y autobiográficos. Trad. Juan Antonio Molina Foix, Valdemar, Madrid. (Colección Gótica, 80).

Llopis, Rafael 2013. Historia natural de los cuentos de miedo, Fuentetaja, Madrid.

Marín Pina, María Carmen 2012. "La aventura de la copa encantada del Palmerín de Inglaterra y las leyendas del corazón arrancado”, en De cavaleiros e cavalarias. Por terras de Europa e Américas. Ed. Lênia Márcia Mongelli, Humanitas, São Paulo, pp. 413-423.

Martínez de Mingo, Luis 2004. Literatura y miedo, Edaf, Madrid.

Medrano, Julián de 1998 [1583]. La silva curiosa. Ed. Mercedes Alcalá Galán, Peter Lang, New York.

Montaner, Alberto y Eva Lara 2014. "Magia, hechicería, brujería: deslinde de conceptos", en Señales, portentos y demonios. La magia en la literatura y la cultura espanolas del Renacimiento. Eds. Eva Lara y Alberto Montaner, Sociedad de Estudios Medievales y Renacentistas, Salamanca, pp. 33-184.

Olavarría, María Eugenia 1989. "Lo numinoso: mito y terror", Alteridades. Anuario de Antropología, pp. 113-122.

Pérez de Montalbán, JUAN 2014 [1624]. La fuerza del desengaño, en Sucesos y prodigios de amor. Ed. Enrique Suárez Figaredo, Textos Lemir, 18, pp. 647-666, en http:// parnaseo.uv.es/Lemir/Revista/Revista18/Textos/05_Montalban_Prodigios_de_ Amor.pdf [consultado el 18 de noviembre de 2018].

Pérez Zaragoza, Agustín 1977 [1831]. Galería fúnebre de espectros y sombras ensangrentadas. Ed. Luis Alberto de Cuenca, Editora Nacional, Madrid.

RIQUER, IsABEL DE 2007. El corazón devorado: una leyenda desde el siglo XII hasta nuestros dias, Siruela, Madrid.

RoAs, DAVID 2000. La recepción de la literatura fantástica en la España del siglo XIX, Universitat Autònoma de Barcelona, Barcelona.

RoAs, DAVID 2006. De la maravilla al horror. Los orígenes de lo fantástico en la cultura española (1750-1860), Mirabel, Pontevedra. 
Sánchez-Verdejo, Francisco Javier 2013. "Lo gótico: semiótica, género, (est) ética”, Herejía y Belleza, 1, pp. 23-36, en https://repositorio.uam.es/handle/10486/11847 [consultado el 3 de noviembre de 2018].

Sansovino, Francesco 1563. Cento novelle scelte da' piu nobili scrittori della lingua volgare di M. Francesco Sansovino, Editione Terza, Fr. Rampazetto, Venetia.

Todorov, Tzvetan 1980. Introducción a la literatura fantástica, Premià Editora, México.

ZAYAS, MARÍA DE 2012 [1637]. La fuerza del amor, en Novelas amorosas y ejemplares. Ed. Enrique Suárez Figaredo, Textos Lemir, 16, pp. 470-483, en http://parnaseo. uv.es/Lemir/Revista/Revista16/Textos/04_Zayas.pdf [consultado el 15 de noviembre de 2018].

Zerari, MARÍA 2014. "Furor in fabula: La cruel aragonesa de Castillo Solórzano (o de la dama monstruo)", Edad de Oro, 33, pp. 241-256; doi: 10.15366/edadoro2014.33.015. 